\title{
Use of Benchmark Methodology in Environmental Impact Assessment
}

\author{
Jelena Pubule, Institute of Energy Systems and Environment, Riga Technical University, Dagnija Blumberga, \\ Institute of Energy Systems and Environment, Riga Technical University
}

\begin{abstract}
Every industrial activity and procedure influences the environment and climate change. This impact has to be assessed and therefore the procedure of Environmental Impact Assessment (EIA) including the application of a benchmark methodology has been developed. The developed benchmark methodology can be used in the initial assessment as a screening method. The article surveys the developed benchmark methodology for impact assessment of the projects providing extraction of dolomite in the deposits of mineral resources. The benchmark methodology developed makes it possible to assess the impacts caused by the provided activity by objective considerations, to conduct comparison of different projects and evaluate whether the provided activity corresponds to the principles of sustainable development.
\end{abstract}

Keywords - benchmark methodology, criteria, eco-indicators, Environmental Impact Assessment.

\section{I.INTRODUCTION}

Every industrial activity and procedure influences the environment and climate change: each to a lesser or greater extent. This impact has to be assessed and therefore the procedure of Environmental Impact Assessment (EIA), including the application of a benchmark methodology has been developed. The developed benchmark methodology can be used in the initial assessment as a screening method.

In Latvia, the Environmental Impact Assessment procedure has been carried out for more than ten years and during these years impact assessments of many projects have been conducted. For most of the projects, an initial assessment is conducted based on the results of which a decision on the application or non-application of the procedure of Environmental Impact Assessment is made.

Requirements for the performance of the initial assessment are stipulated by national legislative acts, however there is not a united approach developed in Latvia for the assessment of the impact, no methodology, limiting values, or criteria developed. Currently, the initial assessment is carried out only based upon environment quality standards, emission limiting values and limits set by legislative acts. In Latvia, there are no developed and tested criteria for impact assessment which could improve the quality of the assessment and promote the establishment of a unified approach throughout the country. Identification and definition of allowable impact in connection with the provision of sustainable development is a significant step towards further development of Environmental Impact Assessments [1]. The article surveys the developed benchmark methodology for impact assessment of the projects providing extraction of dolomite in the deposits of mineral resources. The methodology is based on the use of the criterion of impact assessment - eco-indicator. The benchmark methodology developed makes it possible to assess the impacts caused by the provided activity by objective considerations, to conduct a comparison of different projects and evaluate whether the provided activity corresponds to the principles of sustainable development.

\section{II.EXTRACTION OF MINERAL RESOURCES AND EIA IN LATVIA}

In Latvia from the more than 4000 scheduled activities for which impact assessments have been carried out, initial assessments have been conducted for $96 \%$ of them. Currently there limiting values of scheduled activities have been developed, e.g. the area of the mining field, the production capacity, etc, defining, whether the procedure of EIA or initial assessment should be applied to the activity.

There is no disagreement concerning projects for which the procedure of EIA is required by normative acts - the procedure is applied, while projects that by normative acts are subject to initial assessment bring about uncertainty. When the initial assessment is carried out for the scheduled activity, the decision on the application or non-application of the procedure of Environmental Impact Assessment is made based on the results of the initial assessment. However, in Latvia there is no procedure, or methodology developed, that would help the experts conducting the initial assessments, to make unified decisions. It is not clear how these potential impacts are assessed, nor how their importance is evaluated, neither how potential indirect or cumulative impacts are identified.

EIA methods range from simple to complex, requiring different kinds of data, different data formats, and varying levels of expertise and technological sophistication for their interpretation [2].

The combined, incremental effects of human activity, referred to as cumulative impacts, pose a serious threat to the environment. While they may be insignificant by themselves, cumulative impacts accumulate over time, from one or more sources, and can result in the degradation of important resources [3]. Several methods may be used for the identification and gathering of data on cumulative environmental impacts, such as, conceptual models, interactive matrixes, nettings and procedures of adaptive management $[4,5]$.

In Latvia control sheets are used for the Environmental Impact Assessment procedure to evaluate the relevance of the predictable impacts of a planned activity. In these control 
sheets, the relevance of the possible factors must be evaluated by "yes" or "no". However, there is no criteria developed for defining this relevance. At present, in Latvia no control sheets or matrixes nor any other conventional evaluation models are applied to the initial assessment of environmental impact. In the legislation of Latvia activity groups undergoing initial assessment have not been stated clearly, and neither the criteria nor limiting threshold to be applied for initial assessment, according to which the possible impact should be evaluated, are set, thus leaving space for subjective evaluation and voluntary approach [6]. Such a situation burdens the decision-making process, makes it open to conflicts and gives an opportunity to take advantage of weak environmental legislation.

Within the research the most relevant of possible impacts, related to mining, have been analyzed and patterned and, based upon this assessment, criteria have been chosen - the ecoindicators, potentially useful in impact assessment.

Minerals produced in Latvia are mostly used as either construction materials or as raw materials for production: gypsum, limestone, dolomite, clay, and sand - gravel mix, sand. Currently in Latvia there is a sufficient supply of mineral resources such as sand, dolomite and peat. Nevertheless, efficient use of mineral resources is one of the conditions to ensure sustainable development of the country.

Over the past years in Latvia, the volume of extraction of mineral resources has increased on average four times [7]. If one is to analyze the most frequent types of mineral deposits, the conclusion can be made that minerals such as dolomite and sand-gravel mix are utilised in economic circulation disproportionally to the existing reserves. In 2008 sand and sand-gravel mix extraction composed 7,5 million $\mathrm{m}^{3}$ and dolomite extraction -2 million $\mathrm{m}^{3}$ [8].

While the research was done, in legislative acts in Latvia it was stated that the procedure of EIA had to be applied to projects suggesting mining in mineral deposit fields previously not explored with an area exceeding 25 hectares or peatbogs exceeding 150 hectares. Irrespective of the area intended for the extraction. The initial assessment was applied to deposit fields larger that 5 hectares and peatbogs larger that 25 hectares. Comparing the initial assessments of mineral extraction, it was found that until July 2010, the criterion determing whether the procedure of EIA should be applied, was the area of the deposit field. According to the normative acts in Latvia, the mineral deposit field is a natural aggregate of mineral resources, the quantity and quality and mining conditions of which have been evaluated and practical utilisation is possible. Thus the area of the extraction was defined by the client and it was not directly related to the natural mineral deposit itself.

However, currently according to amendments of law of July $14^{\text {th }} 2010$, the procedure of EIA has to be applied to projects suggesting mining in mineral deposit fields with an area of 25 hectares or more or peatbogs exceeding 150 hectares. The initial assessment must be applied to projects suggesting mining in mineral deposit fields with an area of 5 or more hectares or peatbogs with an area of 25 or more hectares.

From all the initial assessments on mineral deposit extraction in Latvia, the procedure of EIA have been applied only to those projects, supposing to explore fields larger that 10 hectares. However, it is inferable that some applicants indicate the area of the extraction smaller than they actually intend to explore on purpose to avoid the procedure of EIA. Later on, the extraction field is extended, but the procedure of EIA has been bypassed. Taking this into account, it is considered that the area of deposit field can not be the only criterion, determining the application or non-application of the Environmental Impact Assessment procedure.

\section{III.RESEARCH METHODOLOGY}

Today different data processing methods exist in the world that makes it possible to assess the environmental impact, from complex life cycle analyses, including the effect of the product or activity to climate changes, environmental health, process efficiency and other impacts, to more simple benchmark methodology which makes possible to define the limiting values of environmental impact indicators depending on independent variables. As well there are methods of economic analyses and risk estimate and other. In this article, the benchmark methodology is based on identification of criteria used in benchmark methodology consisting from the following steps:

1. Data collection on Environmental Impact Assessment projects in Latvia;

2. Identification and verification of quantitative and qualitative indicators used in Environmental Impact Assessment;

3. Development of criteria and apply of benchmark methodology.

Detailed research of methodology and data sources used schematically is shown in the flow chart below in Fig. 1.

Two kinds of data from two information sources are collected - data from the Environment State Bureau on projects intended for mining. 250 projects have been surveyed, for which Environmental Impact Assessments have been conducted (initial assessment or procedure of Environmental Impact Assessment).

The second kind of data collected was the Latvian Environment, Geology and Meteorology Centre's regional statistics about mining in Latvia. 


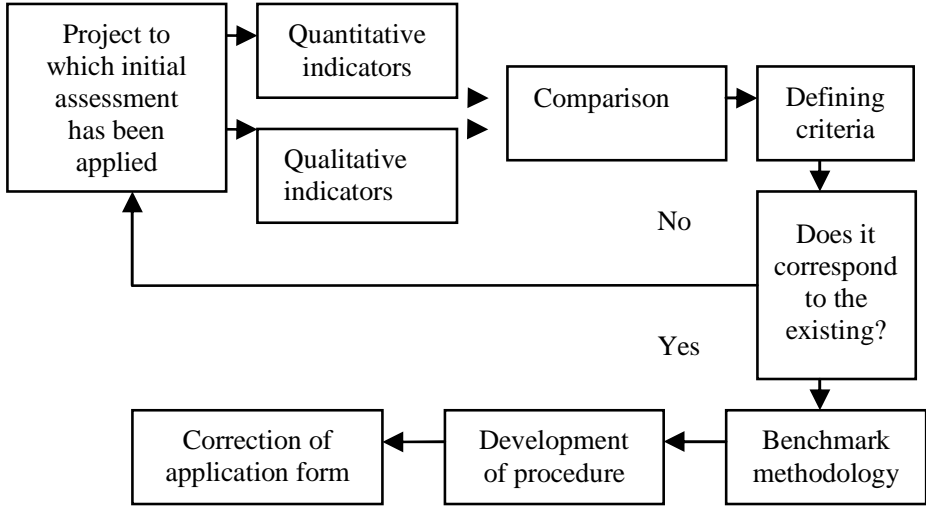

Fig. 1. Methodology for development of criteria used in benchmark methodology.

\section{IV.CHOICE OF INDICATORS}

During the research, special attention was paid to the deposits of dolomite. When extracting dolomite, mining often is done under groundwater level which includes pumping of groundwater and drainage of wastewater in the water body.

The benchmark methodology has been developed for assessment of the impact suggesting the use of eco-indicators as the criteria. Below the criteria for impact assessment are stated:

- Criteria of efficient use of natural resources; When mining, it must be considered, whether the environmental resources (earth, soil, forests, mineral resources, groundwaters) are utilized effciently. Therefore, within dolomite mining, it is suggested to use the volume of mining per area unit per year $(\mathrm{m} 3 / \mathrm{ha}$ per year) as an ecoindicator. That would make it possible to objectively assess the volume of the planned mining field and judge the effectiveness of resource utilization. When mining how effective natural resources are being used (land, soil, forests, mineral resources, and groundwater) should be considered. Therefore it is proposed to use the amount of mining per area unit in the year $\left(\mathrm{m}^{3} /\right.$ ha per year) as an eco-indicator in the field of extraction of dolomite, which allows to objectively assess the volume of extraction of the planned deposit and to judge the effective use of the resources in an objective way.

- Criteria characterising the changes in hydrologic regime;

Interference in the groundwater system may result in changes in the hydrologic regime to a greater or lesser extent. These changes may lead to the drawdown of the groundwater level depression cone - in the adjacent areas.

The level of the groundwater within the influenced zone of the depression cone may be reduced for at least one meter in the outer edge. In order to calculate the diameter of the depression cone, hydrological studies are conducted on the drawdown of groundwaters may influence individual water supply within the influence zone of the depression cone, therefore these aspects are taken into consideration when assessing the environmental impact.

- Criteria for assessing the cumulative impact;

Mining may cause cumulative environmental impact if mining takes place in the adjacent areas. Explicit cumulative impact may be observed when dolomite mining is under the groundwater level and interaction of depression cones provoked by adjacent mining fields occurs.

The significant cumulative impact currently left without attention is the potential pollution of the groundwater.

The main cumulative impact within mineral deposit extraction is planned or existent mining in adjacent territories. Currently, when the initial assessment of environmental impact of mining is made, the volume, area, technologies of production and changes in hydrologic regime that might occur if perspective projects will be implemented, are not taken into consideration. The impact is assessed separately for each project that includes separate assessment of groundwater level changes, volume of depression cone, etc. This approach is considered to be faulty. If mineral deposits are extracted in adjacent territories, the common impact must be assessed as cumulative impacts may occur, and, for example the information from geological studies and the program of monitoring of groundwaters can not give the view of the real situation and possible cumulative impacts.

The complete identification of the cumulative impacts in case of the initial assessment is possible only if each case is examined separately, therefore to consider such general criteria of impact as absolute would not be correct, nevertheless this can help as grounds for further research and identification of cumulative impacts. There are cases when mining fields are located close to one other, but impacts are being assessed for each project separately or in the best case, the adjacent field is mentioned in the assessment.

One of the most significant potential cumulative impacts in mining is the potential pollution of groundwaters. Mineral resources are like natural protection mechanisms holding up the pollution from surface runoff, to enter groundwaters. If deposits are extracted under the groundwater level, this natural protection mechanism is destroyed and groundwaters may get polluted with the pollution from surface water-body (runoff containing agriculture or petroleum product or other pollution). Due to the depression cone, the movement of pollution within the cone's area is intensified, as it is related to the changes of the pressure in the area influenced by the depression cone. In case of a deeper depression cone this impact may intensify.

- Criteria describing emissions into the environment Waste Management is not defined separately as a priority of the Latvian National Environmental Policy. Due to the lower priority compared to other environmental problems, specialized operations were not aimed at the investigations and inventory of the mining sites in connection with the studies of mining waste and associated environmental problems in Latvia so far. There are no tasks or plans regarding mining waste on the national level at the moment [9].

If groundwaters are drained, the wastewaters of production, in this case- groundwaters- must be drained too. The solution for wastewater draining demands special attention when mineral deposits are extracted combined with groundwater drainage. At first, the treatment of groundwater has to be done before draining into natural water body as the water is polluted with suspended particles. 
Secondly, calculations have to be made on whether the receiving water body is able to receive such a volume of wastewater. It is particularly outstanding when wastewaters from several mining fields are drained into one waterbody. As the wastewaters from mineral deposit fields are frequently polluted with suspended particles, in case of insufficient treatment, drained waters may negatively influence fish resources which, in turn, would influence the bird population, etc. Insufficient wastewater treatment and drainage may cause additional indirect and cumulative impacts. In the EU alone the total length of watercourses polluted by mine drainage may exceed $5000 \mathrm{~km}[10]$.

- Criteria influencing changes of the climate

Greenhouse gas emissions form through the consumption of electricity. Electricity is necessary for operating mining devices. The choice of the devices and efficiency of operating determines how much of $\mathrm{CO}_{2}$ emission gets into air basin.

Another consumer of electricity are the pumps of water drainage, the use of which is sometimes inexpedient or even unjustifiable.

The results of setting the benchmark of the criterion of the climatic impact assessment are not illustrated in this article.

\section{ANALYSIS OF RESULTS}

\section{A. Criteria for the efficient use of natural resources}

The correlation of the volume of dolomite extraction and the area of the mining field is charted in Figure 2. The results acquired indicate that, by increasing the area of the mining field, the volume of mineral extraction decreases, thereby mining in the deposit fields with area exceeding 25 ha is not efficient.

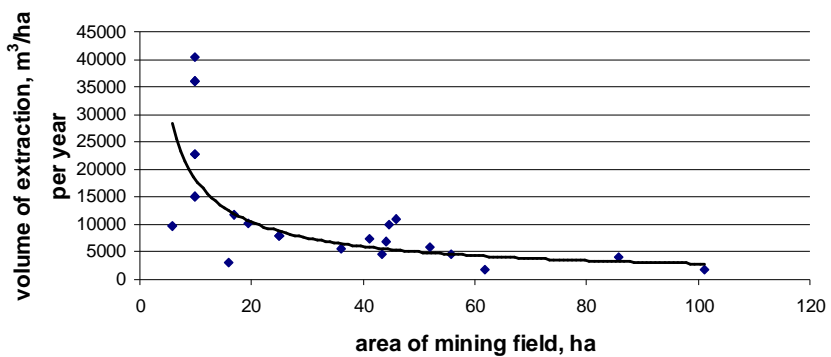

Fig. 2. The specific correlation between volume of extraction and the area of the mining field.

Although the results of regression analysis indicate that data correlation $\left(\mathrm{R}^{2}=0,5938\right)$ could be better, it is allowed to use the equation below in the first approximation for calculation of specific volume of dolomite depending on the area of the deposit:

$$
\mathrm{g}=114084 \cdot \mathrm{F}^{-0,7981}
$$

where

g - Specific volume of dolomite, $\mathrm{m}^{3} /$ ha per year;

$\mathrm{F} \quad$ - Area of the mining field, ha.

\section{B. Criteria characterising the changes in hydrologic regime}

As for the eco-indicator in the benchmark methodology it is proposed to use the radius $(\mathrm{km})$ of the depression cone per the area (ha) intended for the mining. This eco-indicator makes it possible to compare different projects. (see Fig. 3).

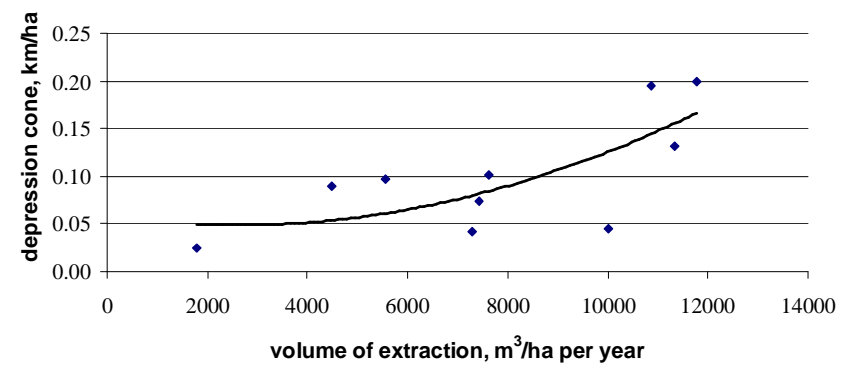

Fig. 3. The compatibility of eco-indicators of specific depression cone and specific volume of dolomite extraction.

Although the results of regression analysis indicate that data correlation $\left(\mathrm{R}^{2}=0,5214\right)$ could be better, it is allowed to use the following equation in the first approximation for calculation of specific depression cone depending on the volume of extraction:

$$
\mathrm{s}=1 \cdot 10^{-9} \cdot \mathrm{g}^{2}-7 \cdot 10^{-6} \cdot \mathrm{g}+0,0574
$$

where

$\mathrm{s}$ - $\quad$ Specific depression cone, $\mathrm{km} / \mathrm{ha}$;

g- $\quad$ Specific volume of dolomite, $\mathrm{m}^{3} /$ ha per year.

\section{Criteria for assessment of cumulative impacts}

As for the eco-indicator in the benchmark methodology it is proposed to use the depth of mining from surface $(\mathrm{m})$ per the area intended for the mining (ha). The depth is related to develping of the depression cone (see Fig. 4.)

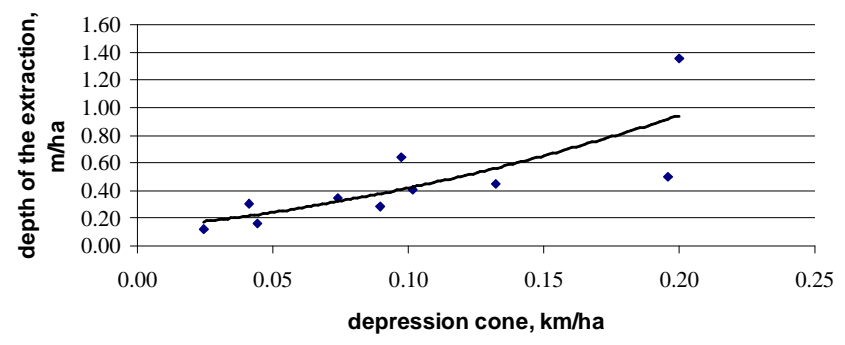

Fig. 4. Correlation of the specific depth of mining and the specific depression cone.

The results of regression analysis and data correlation $\left(\mathrm{R}^{2}=0,6107\right)$ indicate that it is possible to use the following equation in the first approximation for calculation of specific depth of the extraction depending on the size of specific depression cone:

$$
\mathrm{q}=11,411 \cdot \mathrm{s}^{2}+1,8056 \cdot \mathrm{s}+0,1248
$$

where

$\mathrm{q} \quad$ - Specific depth of mining, $\mathrm{m} / \mathrm{ha}$;

$\mathrm{s} \quad$ - Specific depression cone, $\mathrm{km} / \mathrm{ha}$. 


\section{Criteria describing emissions into environment}

As for the eco-indicator in benchmark methodology, it is proposed to use the volume of the wastewaters $\left(\mathrm{m}^{3}\right)$ per area intended for mining (ha) per. The volume of the wastewater depends on the depression cone (see Fig. 5.).

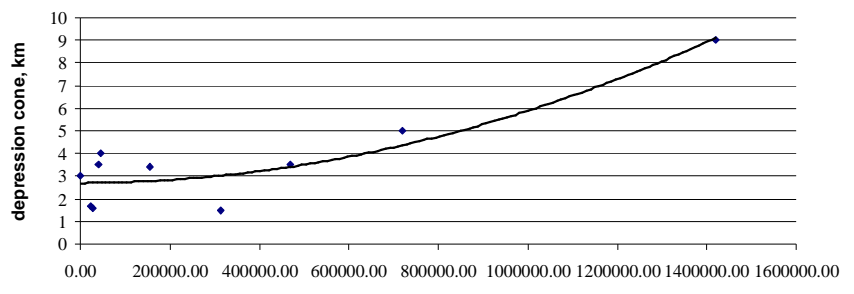

volume of wastewater, $\mathrm{m}^{3} /$ ha per year

Fig. 5. The correlation between specific volume of the wastewater and specific depression cone.

The results of regression analysis and data correlation $\left(\mathrm{R}^{2}=0,8229\right)$ indicate that it is possible to use the below equation in the first approximation for calculation of the specific volume of wastewater depending on the size of specific depression cone:

$$
\mathrm{h}=3 \cdot 10^{-12} \cdot \mathrm{S}^{2}+6 \cdot 10^{-8} \cdot \mathrm{S}+2,6969
$$

where

h - Specific volume of wastewater, $\mathrm{m}^{3} / \mathrm{ha}$ per year;

$\mathrm{S} \quad$ - Depression cone, $\mathrm{km}$.

\section{VI.DISSCUSSION}

The results acquired and empiric benchmark equations can be used in determined range of indicator values:

- The area of mining $\mathrm{F}=5,73-101$ ha,

- The specific volume of dolomite extraction, $\mathrm{g}=1783-40404 \mathrm{~m}^{3} /$ ha per year,

- The specific depression cone, $\mathrm{s}=0,02-0,2 \mathrm{~km} / \mathrm{ha}$,

- The specific depth of mining, $\mathrm{q}=0,12-1,35 \mathrm{~m} / \mathrm{ha}$,

- The specific volume of wastewater, $\mathrm{h}=912500-65335000 \mathrm{~m}^{3} /$ ha per year.

- The depression cone, $\mathrm{S}=1,5$ - $9 \mathrm{~km}$.

Considering the result acquired, it can be assumed that benchmark methodology can be applied to Environmental Impact Assessment of dolomite mining. The application of benchmark methodology in the EIA process for dolomite mining will enable improving the quality of assessing and will promote expedient utilization of natural resources and sustainable development.

\section{FIRST CONCLUSIONS AND FUTURE WORK}

1. In the past years the number of procedures of Environmental Impact Assessment applied to mineral deposit mining has increased. The criterion identifying application of the procedure of Environmental Impact Assessment is the area of the deposit field irrespective of the volume of the material to be extracted. It is necessary to implement a systems approach in the procedure of EIA.

2. Efficient utilization of mineral deposits is one of the core principles of sustainability. Therefore, when evaluating and comparing the projects, those should be approved for implementation which the larger volume of mineral deposits would be extracted and the land would be used more expediently. The criterion applicable for comparison of different projects within the field of mineral deposits is the volume of deposit extraction per area of mining per year. The benchmark equation described above, can be used to evaluate the efficiency of suggested production and to determine whether this activity complies with the principles of sustainable development.

3. Special attention in the field of mineral deposits should be paid to the projects intending extraction under the groundwater level or related to groundwater draining. Such an activity may stimulate changes in the hydrologic regime that may cause direct, indirect and cumulative impacts on the environment. Currently, the risk of groundwater pollution caused by mining under groundwater level is not taken into consideration nor is analysed. The depression cone and changes in the hydrologic regime may lead to groundwater pollution with polluting substances from surface water, as well as with pollution from the ground. Now, when assessing the impacts caused by the depression cone, only changes in the individual water supply of adjacent houses is taken into consideration but the risk of underground water pollution is not analyzed at all. Benchmark equations described above can be used to define the area of the depression cone, its area of influence and for determining the volume of the additional exploration concerning the potential pollution of underground waters and the environmental impact created by interaction of nearby standing extraction fields.

4. In the process of EIA, the principles of the life cycle are not considered. The studies should be conducted to find out what is more environmentally friendly - to mine the mineral deposits in Latvia or, utilize for construction for example, the recycled asphalt from Latvia or any other European country. For projects that are subject of EIA procedure, life cycle analyses must be done.

\section{REFERENCE}

1. Defining an Acceptable Level of Environmental Impact [Online]. The global development research center (Tex.), [Accessed 14.12.2009.]. Available: http://www.gdrc.org/uem/e-mgmt/e-mgmt.html\#3app-6/.

2. Environmental Impact Assessment Regulations and Strategic Environmental Assessment Requirements, 2006. - Washington: The World Bank, 2006.

3. Consideration of Cumulative Impacts in EPA Review of NEPA Documents, 1999. - U.S. Environmental Protection Agency, Office of Federal Activities, 1999.

4. Considering Cumulative Effects Under the National Environmental Policy Act., Executive Office of the President, 1997. - Washington: Council on Environmental Quality, 1997.

5. Fischenich J. The Applicance of Conceptual Models to Ecosystem Restoration, 2008. - ERDC/EBA TN-08-1., 2008.

6. Danilāne D., Gavena I., Kāla A. Environmental Impact Assessment. Riga: Landmark, 2002, 208 p.

7. Overview of sustainable development indicators, 2006 - R.: Latvian Environment, Geology and Meteorology agency, 2007. 
8. Mineral resources (construction materials, peat and healing mud) stock balance for year 2008, 2009 - R.: Latvian Environment, Geology and Meteorology agency, 2009.

9. Jordan G. D', Alessandro M. Mining, mining waste and related Environmental issues: problems and solutions in Central and Eastern European Candidate Countries 2004. Ispra: Joint research Centre of the European Commission, LB-NA-20868-NE-C, 2004.

10. Younger P., Banwart S. And Hedin R. Mine Watyer; Hydrology, Pollution, Recomendation. Dordrecht: Kluwer Academic Publishers.

Jel̦ena Pubule, M. Sc., Researcher
Institute of Energy Systems and Environment, Riga Technical University Kronvalda bulvaris 1, Riga, LV-1010

Phone: +37129485141

e-mail: jelena.pubule@rtu.lv

Dagnija Blumberga Dr. hab. sc. ing., Professor, Director Institute of Energy Systems and Environment, Riga Technical University

Kronvalda bulvaris 1, Riga, LV-1010

Phone: +37167089901

e-mail: dagnija.blumberga@rtu.lv

\section{Jẹ̦ena Pubule, Dagnija Blumberga. Līmeṇatzīmes metodes lietošana ietekmes uz vidi novērtēšanā}

Jebkura rūpnieciska darbība un process ietekmē vidi un klimata pārmainas: viens mazāk, bet cits vairāk. Šì ietekme ir jāvērtē un tādēl ir izstrādāta ietekmes uz vidi vērtēšanas (IVN) procedūra, kas ietver līmeņatzīmes metodes izmantošanu. Izstrādātā līmenatzīmes metode var tikt izmantota sākotnējā izvērtējumā kā sākotnējās atlases metode. Latvijā ietekmes uz vidi novērtējuma process tiek veikts jau vairāk kā desmit gadus un šo gadu laikā ir veikti daudzu projektu ietekmes vērtējumi. Lielākajai dalai projektu tiek piemērots sākotnējais izvērtējums, uz kura rezultātiem tiek pienemts lēmums par ietekmes uz vidi novērtējuma procedūras piemērošanu vai nepiemērošanu. Valsts normatīvajos aktos ir atrunātas prasības sākotnējā vêrtējuma veikšanai, tomēr valstī nav izstrādāta vienota pieeja ietekmes vērtěšanai, nav izstrādātas metodikas, robežvērtības, kritēriji. Šobrī̉ sākotnējais vērtējums tiek veikts tikai pamatojoties uz normatīvajos aktos noteiktiem vides kvalitātes normatīviem, emisiju robežvērtībām un limitiem. Latvijā nav izstrādāti un aprobēti kritēriji ietekmes vērtěšanai, kas uzlabotu vērtējuma kvalitāti un sekmētu vienotas pieejas veidošanu visā valsts teritorijā. Rakstā ir apskatīta izstrādātā līmennatzīmes metode projektu, kas paredz dolomìta ieguvi derīgo izraktenu atradnēs, ietekmes vērtēšanai. Metode balstīta uz ietekmes vērtēšanas kritēriju - ekoindikatoru - izmantošanu. Izstrādātā līmenatzīmes metode ḷauj objektīvi novêrtēt paredzētās darbības izraisītās ietekmes, veikt dažādu projektu salīdzināšanu un novērtēt vai paredzētā darbība atbilst ilgtspējīgas attīstības principiem. Līmenatzīmes metodē tiek piedāvāts izmantot sekojošus kritērijus ietekmes vērtěšanai: dabas resursu lietderīgas izmantošanas kritēriji; kritēijii, kas raksturo hidroloğiskā režīma izmainas; kritēriji kumulatīvo ietekmju izvērtēšanai; kritēriji, kas raksturo emisijas vidē; kritēriji, kas ietekmē klimata pārmaiņas.

\section{Елена Пубуле, Дагния Блумберга. Использование методики отметки уровня в оценке влияния на окружающую среду}

Любая хозяйственная деятельность и процесс влияет на окружающую среду и климат: одна меньше, другая больше. Необходима оценка этого влияния, поэтому разработана процедура оценки влияния на окружающую среду, которая предусматривает использование методики отметки уровня. Разработанную методику отметки уровня можно использовать для проведения начальной оценки влияния на окружающую среду. В Латвии процесс оценки влияния на окружающую среду проводится уже более 10 лет и в течение этих лет была проведена оценка многих проектов. Большинству проектов проводилась начальная оценка влияния на окружающую среду, на основании результатов которой принимались решения о применении или не применении процедуры оценки влияния на окружающую среду. В государственном законодательстве оговорены требования для проведения начальной оценки влияния на окружающую среду, однако, в нормативных актах не выработан единый подход к оценке влияния на окружающую среду, не разработаны методики, допустимые нормы, критерии. В настоящее время начальная оценка влияния на окружающую среду проводится только на указанных в нормативных актах качественных показателях, допустимых эмиссиях и лимитах. В Латвии нет разработанных и опробованных критериев оценки влияния на окружающую среду, которые могли бы улучшить качество оценки и способствовать выработке единого подхода к оценке влияния на окружающую среду на всей территории Латвии. В статье описана методика отметки уровня для оценки влияния на окружающую среду проектов разработки полезных ископаемых - добычи доломитов. Методика основана на использовании критериев - экологических индикаторов. Разработанная методика отметки уровня позволяет объективно оценить влияние предполагаемой деятельности на окружающую среду, сравнить различные проекты и оценить соответствие предполагаемой деятельности принципам устойчивого развития. Мелодика предполагает использование следующих критериев оценки влияния на окружающую среду: критерии полезного использования природных ресурсов; критерии, характеризующие изменения гидрологического режима; критерии для оценки кумулятивных влияний; критерии, характеризующие эмиссии в окружающую среду; критерии, которые влияют на изменения климата. 